\title{
Cytological Irregularities in Hybrids between Species of Wheat with the Same Chromosome Number*
}

\author{
By \\ W. P. THOMPSON and H. T. ROBERTSON \\ (With Plate 15) \\ Reccizicl Jinuary 35,1930
}

Observations on the fertility and genetics of crosses between species of wheat with the same chromosome number have usually indicated normal cytological behavior. Complete homology of the chromosomes of all species within each cytological group has usually been assumed in the numerous discussions regarding the relationships of the chromosomes in the different groups of wheat, Aegilops, and rye. Nevertheless it has been shown that homology may not be complete even for different varieties of the same species (GOULDEN 1925; THOMPSON 1928), and unpublished observations have shown that this is true also in certain hybrids between species within the same group.

Furthermore the studies of WINGE (1924), confirmed and extended by Huskins (1928), suggested the possibility that there may not be complete homology as between Triticum vulgare and T. Spelta. These authors concluded from cytological studies on speltoid mutations in vulgare that if 1 of the 7 groups of 6 chromosomes in that species be designated $\frac{A B C}{A B C}$. a heterozygous speltoid is $\frac{A B C}{A B B}$, a homozygous speltoid $\frac{\mathrm{ABB}}{\mathrm{ABB}}$, a heterozygous compactum $\frac{\mathrm{ABC}}{\mathrm{ACC}}$, and a homozygous

* This investigation was carried on in part at the University of Saskatchewan, Canada, and in part at the Division of Genetics, University of California. We are indebted to the National Research Council of Canada for financial assistance and to Professor E. B. BABCOCK for the use of the facilities of the Division of Genetics at Berkeley. 
compactum $\frac{\text { ACC }}{\text { ACC }}$ Their conclusions are based on their observation of univalent chromosomes (presumably the c) and trivalents (presumably the $3 \mathrm{Bs}$ ) in heterozygous speltoids and other appropriate irregularities in various extracted types.

It seems probable that pure Spelta and compactum differ from vulgare in much the same way as extracted homozygous speltoids and compactums respectively. HuskiNs (1927) has in fact suggested that vulgare be designated $\frac{\mathrm{ABC}}{\mathrm{ABC}}$. Spelta $\frac{\mathrm{AB}_{1} \mathrm{~B}_{2}}{\mathrm{AB}_{1} \mathrm{~B}_{2}}$. and compactum $\frac{\mathrm{AC}_{1} \mathrm{C}_{2}}{\mathrm{AC}_{1} \mathrm{C}_{2}}$. If the pure forms are related to the extracted ones and if the conclusions of WINGE and HUSKINS are correct it may be anticipated that the $\mathrm{C}$ chromosome of vulgare would find no proper mate in hybrids with Spelta, and that the B would find none in hybrids with compactum.

A similar theory was proposed on genetic grounds by MALINOWSKI (1926) regarding the 28-chromosome group of species. He suggested that 2 non-homologous chromosomes of polonicum be designated a and $\mathrm{b}$, of dicoccum a and $\mathrm{c}$, and of durum $\mathrm{c}$ and $\mathrm{d}$. (In order to bring the formulae into agreement with those used for the vulgare group HuskINS suggested $\mathrm{AB}$ for durum, $\mathrm{B}_{1} \mathrm{~B}_{2}$ for dicoccum, and $\mathrm{CB}$ for polonicum). The mating in polonicum $\times$ dicoccum must be $\frac{\mathbf{a}}{\mathbf{a}} \frac{\mathbf{b}}{\mathbf{c}}$, in dicoccum $\times$ durum $\frac{\mathrm{c}}{\mathrm{c}} \frac{\mathrm{a}}{\mathrm{d}}$, and consequently in polonicum $\times$ durum $\frac{a}{d} \frac{b}{c}$. The latter mating should give many dicoccum (ac) plants. But that is not the case. Therefore if there is any basis for the formulae one of two things must happen: Either there is a failure to mate in certain hybrids or the two characteristic chromosomes of each species must always remain associated. Either the failure to mate or the association should be revealed by a cytological examination of the hybrids.

In view of all these considerations a study was undertaken to determine whether the chromosomes of each species of wheat are completely homologous with those of every other species in the same cytological group.

\section{Methods and materials}

Hybrids were produced in nearly all combinations within each group of species and their pollen mother cells were examined for 
unmated chromosomes and other irregularities. In order to decide what significance could be attached to the results it was necessary to know to what extent, if at all, such irregularities occur in the pure species. Consequently these were studied in the same way.

Smear preparations of fixed material, stained with aceto-carmine, were used almost entirely. They were very satisfactory for our purpose because all cells were intact and nearly all presented side views which are best for the study of lagging chromosomes. In each case many cells were examined at all stages from heterotypic metaphase to homotypic anaphase. The slides were surveyed systematically and every cell which was at the proper stage was recorded as showing $0,1,2$ etc. univalents or other irregularities. At the metaphase only those cells were recorded in which a perfectly regular plate had been formed and in which none of the bivalents had disjoined. Only those chromosomes were recorded as laggards which were clearly separated from the plate. In some cases it was difficult to decide whether such chromosomes were univalents or bivalents but usually a decision could easily be made. At anaphase there was almost no difficulty in this respect, the univalents with their equational split standing out clearly between the groups of divided bivalents. In order to make as fair a comparison as possible between pure species and hybrids, no cells were recorded later in the heterotypic division than the stage at which individual halves of bivalents were still clearly discernible, although univalents often remained separate from the groups of bivalents much later than this.

of the different species the varieties which were used were as follows :

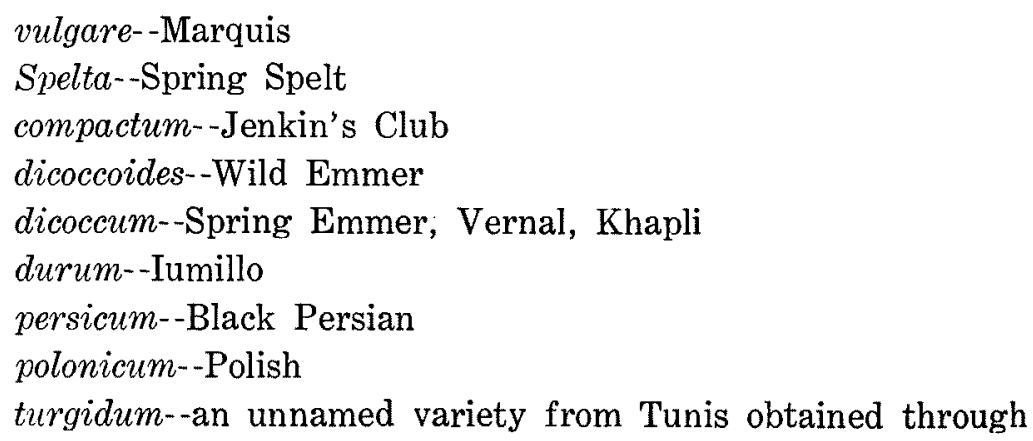




\section{Results}

\section{(a) Vulgare Series}

A considerable proportion of the pollen mother cells of vulgare $x$ Spelta and vulgare $\times$ compactum showed 1 or a few lagging univalent chromosomes. This is true of all stages from heterotypic metaphase to homotypic anaphase. Their appearance and behavior were the same as in hybrids between species which differ in chromosome number. Photographs showing the univalents at the heterotypic metaphase in vulgare $\times$ Spelta are reproduced in Pl. 15, figures 2,3 , and 4 and of vulgare $\times$ compactum in figure 1 . Heterotypic anaphase views from the former are reproduced in figures 4, 5, and 6 and from the latter in 7 and 8. An interphase view from vulgare $\times$ Spelta is shown in figure 9.

The results of counts made to determine the proportion of mother cells in which univalents were visible in the hybrids as well as in the pure lines are given in Table 1 . In vulgare $\times$ Spelta the percentage of cases was more than 40 and in vulgare $\times$ compactum more

Table 1

Frequencies of pollen mother cells with univalent chromosomes in 42-chromosome species of wheat and in hybrids between them.

\begin{tabular}{|c|c|c|c|c|c|c|c|c|c|c|c|c|}
\hline \multirow{4}{*}{ Material } & \multicolumn{10}{|c|}{ Number of lagging univalents } & \multirow{4}{*}{$\begin{array}{l}\text { Total } \\
\text { exam- } \\
\text { ined }\end{array}$} & \multirow{4}{*}{$\begin{array}{l}\text { Percent } \\
\text { irregu- } \\
\quad \text { lar }\end{array}$} \\
\hline & \multicolumn{7}{|c|}{ Heterotype } & \multirow{2}{*}{\multicolumn{3}{|c|}{ Homotype }} & & \\
\hline & \multicolumn{3}{|c|}{ Metaphase } & \multicolumn{4}{|c|}{ Anaphase } & & & & & \\
\hline & 0 & 1 & 2 more & 0 & 1 & 2 & more & 0 & 1 & 2 & & \\
\hline vulgare & 548 & 25 & $\begin{array}{ll}15 & 3\end{array}$ & 467 & 6 & 1 & 1 & 285 & 2 & 0 & 1326 & 4.0 \\
\hline Spelta & 711 & 28 & $17 \quad 2$ & 621 & 8 & 6 & 1 & 229 & 9 & 1 & 1633 & 4.4 \\
\hline compactum & 336 & 19 & 74 & 425 & 2 & 3 & 0 & 151 & 3 & 1 & 951 & 4.1 \\
\hline $\begin{array}{l}\text { vulgare } \\
\quad \times \text { Spelta }\end{array}$ & 248 & 109 & $86 \quad 16$ & 197 & 71 & 40 & 11 & 56 & 27 & 4 & 885 & 42.0 \\
\hline $\begin{array}{l}\text { vulgare } \\
\times \text { compactum }\end{array}$ & 123 & 41 & $\begin{array}{ll}30 & 3\end{array}$ & 141 & 29 & 27 & 1 & 192 & 64 & 48 & 696 & 34.8 \\
\hline $\begin{array}{l}\text { Spelta } \\
\quad \times \text { compactum }\end{array}$ & 622 & 71 & $\begin{array}{ll}53 & 11\end{array}$ & 422 & 41 & 9 & 3 & 511 & 25 & 9 & 1777 & 12.5 \\
\hline
\end{tabular}


than 30. The number of cells examined at every stage was large enough to establish the significance of the observations. The results were consistent from stage to stage and from plant to plant. In each cross the material examined came from several different $F_{1}$ plants.

The proportion of cases in which univalents really occurred may have been considerably higher than that in which they were seen because in many cases they were probably at the edge of the plate in such a position that they were obscured by the bivalents, and at the anaphase of the bivalents they might not always have moved into or lagged in the equatorial position. On the other hand some apparent univalents at the metaphase may really have been bivalents which were slow in moving into the plate, but the number of such cases must have been small because great care was taken in regard to this point. Similarly a few of the apparent univalents at the anaphase may have been halves of bivalents which, after separating from their mates, moved tardily to the poles and split en route. But these cases also must have been very rare because the mate would usually have been present and revealed the real situation.

Moreover any such exceptions would be as numerous in the pure species as in the hybrids and therefore would not affect the comparison. Table 1 shows that even in the pure parents a pair of partners occasionally failed to mate. But the percentage of such cases (about 4) was much lower than in vulgare $\times$ Spelta or in vulgare $\times$ compactum. In Spelta $\times$ compactum the percentage of irregularities was lower than in the other hybrids but higher than in the pure species.

When two univalents were visible they were sometimes rather closely associated while the bivalents were in the metaphase plate. Sometimes a loosely connected bivalent was seen at a distance from the plate.

Rarely an element was observed which might be regarded as a trivalent. This usually had the appearance of a loose bivalent with a univalent attached to one end (or 3 univalents attached end to end). The bivalent occupied the usual position in the plate so that the univalent projected beyond the level of the other chromosomes. In some of these rare cases it is doubtful whether the univalent was really attached to the bivalent or at a slightly different level. We could not identify with certainty any trivalents of the triangular or ring types as described by WINGE and Huskins in heterozygous speltoids. Our inability to demonstrate them beyond question may 
have been due to the fact that our preparations were smears in which all the chromosomes (except univalents) were in every plate and consequently obscured each other in side views. But a preliminary study of thin sections of paraffin material presenting views of portions only of the plates was no more successful.

Several $F_{2}$ plants, chosen so as to include as great a variety of types as possible, were also examined. Most of them appeared to be regular and from counts made in paraffin material to have 42 chromosomes. Two gave counts of 44 and in them complexes apparently consisting of 3 or 4 chromosomes were observed (figure 10).

The observations as a whole may be interpreted in two different ways: (a) The behavior in the hybrids is essentially similar to that in heterozygous speltoids because Spelta and compactum differ from vulgare in the same way as extracted homozygous speltoids and compactums respectively. (b) The pure forms have become so differentiated genetically that the chromosomes in the hybrids have less affinity for each other than in the pure forms and consequently mating is more difficult.

On the basis of the second alternative the irregularities result from a general situation and may not relate to a particular pair of chromosomes but occur now in one pair, now in another. Since the forms which were crossed are placed in distinct taxonomic species the suggestion may be regarded as reasonable. It is supported by the frequent occurrence of 2 or more univalents, by our failure to find trivalents, and by the proportion of cases in which no irregularities were seen.

On the basis of the first alternative vulgare is $\frac{\mathrm{ABC}}{\mathrm{ABC}}$, Spelta $\frac{\mathrm{ABB}}{\mathrm{ABB}}$ (or $\frac{\mathrm{AB}_{1} \mathrm{~B}_{2}}{\mathrm{AB}_{1} \mathrm{~B}_{2}}$ ), and compactum $\frac{\mathrm{ACC}}{\mathrm{ACC}}$ (or $\frac{\mathrm{AC}_{1} \mathrm{C}_{2}}{\mathrm{AC}_{1} \mathrm{C}_{2}}$ ) Vulgare $\times$ Spelta is then $\frac{A B C}{A B B}$ The $C$ would find difficulty in mating with the third $B$ and therefore might be expected to appear as a univalent in a considerable proportion of cases. The third $\mathrm{B}$ might appear as a univalent or, as in heterozygous speltoids, join the other 2 Bs to form a trivalent. The latter phenomenon should be less frequent in hybrids than in speltoids, if it could occur at all, because the 2 Bs of a Spelta gamete must be differentiated (or trivalents and quadrivalents would appear in the pure species) while those of speltoids are recent duplications of the $\mathrm{B}$ of vulgare.

In vulgare $\times$ compactum $\frac{\mathrm{ABC}}{\mathrm{ACC}}$ the situation would be essentially 
similar. In Spelta $\times$ compactum $\frac{\mathrm{ABB}}{\mathrm{ACC}}$ the smaller amount of irregularity may be due to mating between the 2 Bs and between the 2 cs.

If this interpretation is preferred to the other, important genetic consequences should follow. The gametes of vulgare $\times$ Spelta would usually be $\mathrm{ABC}$ and $\mathrm{ABB}$ but occasionally also $\mathrm{ABO}$ (when neither the $\mathrm{C}$ nor the third $\mathrm{B}$ reach a daughter nucleus in the homotypic division) and $A B B C$ (when both reach the same nucleus). The functioning of the latter gametes would disturb the genetic situation. Quite apart from any question of differential viability, however, the functioning gametes would usually be $\mathrm{ABC}$ and $\mathrm{ABB}$.

This cross has been studied genetically by a number of investigators including LEIGHTY and BoshNAKIAN (1921), BoSHNAKIAN (1922) KAJANUS (1923), NILSSON-LEISSNER (1925), MALINOWSKI (1926), and RAUM (1929). Most authors found that the Spelta characters were inherited as a unit and that the spelt complex was dominant to that of vulgare. LEIGHTY and BOSHNAKIAN found a $15: 1$ ratio in some cases and RAUM found 4 vulgare: 6 intermediate: 6 Spelta. Several authors found that compactum-like forms segregate out in small proportions. NiLSSON-LEISSNER showed that while the general $F_{3}$ results agreed fairly well with a 3:1 ratio, a proportion of families were far from expectation, some even giving 1:3 ratios. Most of the authors found it necessary to formulate subsidiary hypotheses of different kinds. The recent elaborate study by RAUM revealed a complex situation. Some of his conclusions are as follows: There is a factor $s$ which when homozygous causes fully developed spelt characters but when heterozygous an intermediate condition; ss is, however, like pure spelt if a second factor $\mathrm{B}$ is homozygous but not if it is heterozygous; $\mathrm{B}$ alone has no effect on glume characters but causes a lengthening of the internodes as does $\mathrm{S}$ itself; ss is suppressed by $\mathrm{CC}$ if $\mathrm{B}$ is absent or heterozygous but not if it is homozygous; ss is not affected by Cc; Ss with CC is vulgare-like unless $\mathrm{B}$ is homozygous when the intermediate condition results; $\mathrm{C}$ shortens the internodes but another factor $\mathrm{A}$ lengthens them; A, B, C and s interact in a very complex way on the length of the internodes. In spite of the number of factors and of their ways of interacting the results could not be brought wholly into agreement with theory.

If WINGE's theory with respect to the speltoids is applicable to the hybrids the genetic difficulties may result in part at least from the cytological irregularities which have been reported in this paper. It 
has been pointed out that although most of the gametes would be ABC and $\mathrm{ABB}$ and therefore most of the $\mathrm{F}_{2}$ regular, gametes of other constitutions also would be formed and produce $F_{2}$, some of which would show a different genetic behavior. But until cytological constitution and genetical behavior have been correlated in studies on plants of later generations it does not seem wise to attempt a detailed speculation in regard to the behavior to be expected.

\section{(b) Emmer Series}

The 28-chromosome species which have been used may be combined in $F_{1}$ in 15 ways. 10 of these kinds of $F_{1}$ have been studied as well as their parents and 2 crosses involving another dicoccum variety Khapli. The results are given in Table 2 . The hybrids all showed a higher percentage of irregularities than the parents, but with the exceptions of the Khapli crosses and durum $\times$ dicoccum it is doubtful whether the differences were great enough to be significant. They probably do not relate to any particular chromosomes but indicate only a general slight decrease in affinity associated with genetic diversity. There is some indication that hybrids between similar species (such as dicoccum and dicoccoides) showed less irregularity than others.

In no case was there the slightest evidence of an association between non-homologous chromosomes such as MALINOwskI's theory involves.

In durum $\times$ dicoccum the percentage of irregular cases was very high (more than 20) and the large number of cells examined (1766) showed that the results were really significant. In the majority of irregular cases 2 univalents were present. Sometimes a loose bivalent lagged. Even when no univalents were visible several of the bivalents were usually composed of 2 units loosely associated end to end. This was true even at earliest metaphase. The large amount of irregularity may depend on the varieties used and might not occur in crosses involving other varieties. It is unfortunate that the variety of dicoccum used in this cross was not the same as in the others; the durum was the same throughout.

The Khapli crosses also were highly irregular. This was true even for the cross with another variety of the same species (dicoccum) in which it is placed by taxonomists. It is significant that Khapli, alone among 28-chromosome wheats so far as we are aware, can be crossed with vulgare only with the greatest difficulty and that the hybrids rarely reach maturity. 
Table 2

Frequencies of pollen mother cells with univalent chromosomes in 28-chromosome species of wheat and in hybrids between them.

\begin{tabular}{|c|c|c|c|c|c|c|c|c|c|c|c|}
\hline \multirow{4}{*}{ Material } & \multicolumn{9}{|c|}{ Number of lagging univalents } & \multirow{4}{*}{$\begin{array}{l}\text { Total } \\
\text { exam- } \\
\text { ined }\end{array}$} & \multirow{4}{*}{$\begin{array}{l}\text { Percent } \\
\text { irregu- } \\
\quad \text { lar }\end{array}$} \\
\hline & \multicolumn{7}{|c|}{ Heterotype } & \multirow{2}{*}{\multicolumn{2}{|c|}{$\begin{array}{l}\text { Homotype } \\
\text { Anaphase }\end{array}$}} & & \\
\hline & \multicolumn{3}{|c|}{ Metapinase } & \multicolumn{4}{|c|}{ Anaphase } & & & & \\
\hline & 0 & 1 & more & 0 & 1 & 2 & more & $\begin{array}{ll}0 & 1 \\
\end{array}$ & 12 & & \\
\hline dicoccoides & 363 & 9 & 4 & 241 & 6 & 0 & 0 & 2802 & 21 & 915 & 3.4 \\
\hline dicoccum & 237 & 5 & 0 & 323 & 8 & 5 & 1 & $374 \quad 0$ & 0 & 956 & 2.3 \\
\hline durum & 282 & 3 & 0 & 158 & 1 & 0 & 0 & $329 \quad 0$ & $\begin{array}{ll}0 & 0\end{array}$ & 775 & 0.8 \\
\hline persicum & 424 & 0 & 0 & 249 & 3 & 0 & 0 & $\begin{array}{ll}132 & 1\end{array}$ & 10 & 809 & 0.5 \\
\hline polonicum & 265 & 20 & 0 & 190 & 1 & 0 & 0 & $378 \quad 5$ & $5 \quad 0$ & 841 & 1.0 \\
\hline turgidum & 49 & 0 & 0 & 76 & 1 & 0 & 0 & $26 \quad 1$ & 10 & 153 & 1.3 \\
\hline $\begin{array}{l}\text { dicoccum } \times \\
\text { dicoccoides }\end{array}$ & 2781 & 162 & 0 & 82 & 7 & 2 & 0 & $250 \quad 2$ & $2 \quad 0$ & 639 & 4.5 \\
\hline $\begin{array}{l}\text { dicoccum } \times \\
\text { polonicum }\end{array}$ & 2251 & $14 \quad 11$ & 0 & 95 & 4 & 2 & 0 & & & 351 & 8.8 \\
\hline $\begin{array}{l}\text { durum } \times \\
\text { dicoccum }\end{array}$ & 116310 & .00202 & 15 & 222 & 28 & 34 & 2 & & & 1766 & 21.5 \\
\hline $\begin{array}{l}\text { durum } \times \\
\text { dicoccoides }\end{array}$ & 2022 & $22 \quad 10$ & 0 & 253 & 7 & 1 & 0 & & & 495 & 8.0 \\
\hline $\begin{array}{l}\text { durum } \times \\
\text { polonicum }\end{array}$ & 2801 & $19 \quad 5$ & 1 & 25 & 1 & 0 & 0 & & & 545 & 7.8 \\
\hline $\begin{array}{l}\text { durum } \times \\
\text { persicum }\end{array}$ & 118 & 1 & 0 & 34 & 2 & 0 & 0 & $227 \quad 3$ & 1 & 386 & 1.8 \\
\hline $\begin{array}{l}\text { turgidum } \times \\
\text { dicoccoides }\end{array}$ & 3102 & $20 \quad 15$ & 2 & 141 & 4 & 2 & 1 & $\begin{array}{ll}358 & 12\end{array}$ & 2 & 867 & 6.7 \\
\hline $\begin{array}{r}\text { turgidum } \times \\
\text { dicoccum }\end{array}$ & 4411 & $13 \quad 11$ & 5 & 152 & 5 & 1 & 0 & & & 618 & 5.5 \\
\hline $\begin{array}{r}\text { turgidum } \times \\
\text { persicum }\end{array}$ & 563 & 85 & 0 & 389 & 6 & 6 & 0 & $\begin{array}{ll}365 & 10\end{array}$ & 2 & 1354 & 2.7 \\
\hline $\begin{array}{l}\text { turgidum } \times \\
\text { polonicum }\end{array}$ & 2251 & $14 \quad 11$ & 0 & 95 & 4 & 2 & 0 & & & 351 & 8.8 \\
\hline $\begin{array}{l}\text { dic. (Vernal) } \\
\times \text { Khapli }\end{array}$ & 2125 & $56 \quad 39$ & 6 & 104 & 15 & 3 & 0 & $219 \quad 43$ & $3 \quad 12$ & 709 & 24.5 \\
\hline durum $\times$ Khapli & 1442 & $23 \quad 21$ & 9 & 37 & 5 & 8 & 0 & $71 \quad 15$ & $5 \quad 12$ & 345 & 26.9 \\
\hline
\end{tabular}


If the Khapli crosses and our durum $\times$ dicoccum be regarded as special cases, there is no cytological evidence of definite chromosome diversity among 28-chromosome species. There is a slightly greater amount of irregularity in the hybrids than in the pure species but this probably is not related to particular pairs of chromosomes. Distinguishing symbols must refer to gene complexes in chromosomes which are still able to mate.

\section{Summary}

In hybrids between different 42-chromosome species of wheat a considerable percentage of pollen mother cells show one or a few univalent chromosomes. Such cells are occasionally seen in the pure species but in a much smaller proportion of cases than in the hybrids. The irregularities may be interpreted in essentially the same way as WINGE has interpreted similar phenomena in heterozygous speltoid mutations : with respect to a group of 6 chromosomes vulgare would be $\frac{\mathrm{ABC}}{\mathrm{ABC}}$, Spelta $\frac{\mathrm{ABB}}{\mathrm{ABB}}$ (or $\frac{\mathrm{AB}_{1} \mathrm{~B}_{2}}{\mathrm{AB}_{1} \mathrm{~B}_{2}}$ ) and compactum $\frac{\mathrm{ACC}}{\mathrm{ACC}}$ (or $\frac{\mathrm{AC}_{1} \mathrm{C}_{2}}{\mathrm{AC}_{1} \mathrm{C}_{2}}$ ) They may also be interpreted as the result of a more general weakened affinity associated with genetic diversity and not relating to particular pairs of chromosomes.

Hybrids in many combinations between species of the 28-chromosome group showed only slightly greater amounts of irregularity than the pure species. In special crosses the proportion was much higher. Except in such cases there is no evidence of specific chromosome diversity. Nor is there any evidence of connection between nonhomologous chromosomes.

\section{Literature cited}

BOSHNAKIAN, S., (1922), The relation of the spelt factor in wheat to rachis internode characters. Genetics 8: 261-275.

Goulden, C.H., (1925), A genetic and cytological study of dwarfing in wheat and oats. Thesis, Univ. Minn. Minneapolis. $37 \mathrm{pp}$.

Huskins, C.L., (1927), On the genetics and cytology of fatuoid or false wild oats. Jour. Genetics 18: $315-364$.

- (1928), On the cytology of speltoid wheats in relation to their origin and genetic behaviour. Jour. Genetics $20: 103-122$.

KaJANUS, B., (1923), Genetische Untersuchungen an Weizen. Bibliotheca Genetica $5: 1-186$. 
Leighty, C. E., and Boshnakian, S., (1921), The Genetic behavior of the spelt form in crosses between Triticum Spelta and T. sativum. Jour. Agric. Résearch $22: 335-346$.

MALINOWSKI, E, (1926), Linkage phenomena in wheat. Jour. Genetics $17: 157-185$.

Nilsson-Leissner, G., (1925), Beitrăge zur Genetik von Triticum Spelta und T. vulgare. Hereditas $7: 1-74$.

RaUM, H., (1929), Untersuchungen über die Vererbung des durchschnittliche Ährchenabstandes und des Spelzenschlusses bei Weizen. Bibliotheca Genetica 14:1-172.

Thompson, W.P., (1928), The genetics and cytology of a dwarf wheat. Trans. Royal Society Canada 22 : $335-348$.

WINGE, Ö., (1924), Zy tologische Untersuchungen über speltoide und andere mutantenliche Aberranten beim Weizen. Hereditas 5 : 241-286.

\section{Explanation of Plate 15}

All figures except number 10 are photomicrographs of aceto-carmine preparations of pollen mother cells showing univalents. Figure 10 is from a paraffin section and shows a large complex. Figures 1, 7, and 8 are from vulgare $\times$ compactum and the others from vulgare $\times$ Spelta. Magnification of $1,2,7,9$, and 10 is 450 and of the others 700 . 


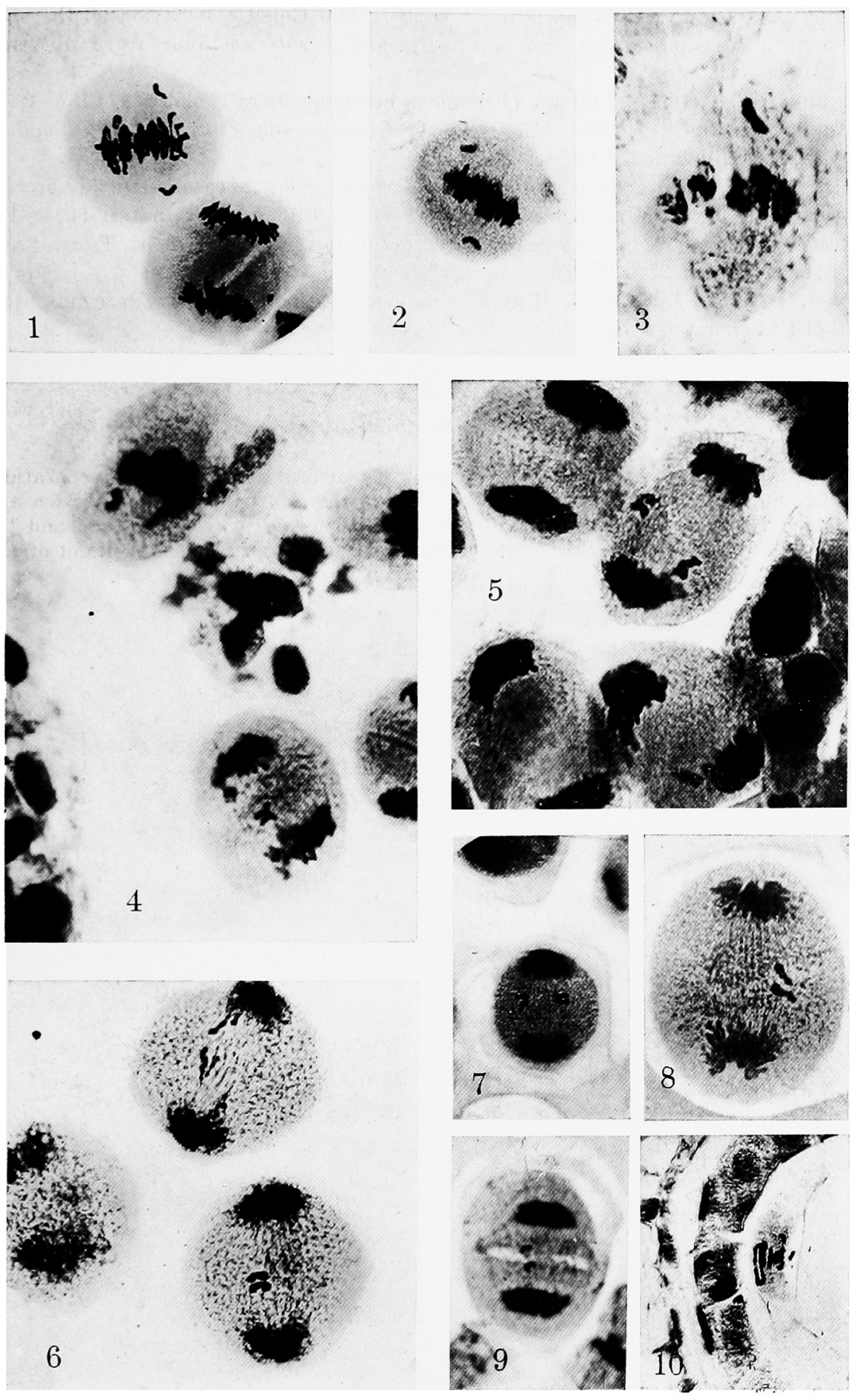

Thompson and Robertson: Chromosome irregularities in wheat 